As we have spent research time, money and bureaucracy on the identification and preservation of wetlands, biologists have begun to see the further encroachment on lands which are seasonally flooded but do not have the distinction of being wetlands.

Pools of water and the retention of water in a protected setting often occurs in the springtime in many places in forested areas as well as shallow ditches both altered by humans or left by glaciation. With the presence of water, different habitats are created which provide breeding grounds for many invertebrates as well as amphibians, reptiles and birds, become present since the spring is breeding season and the above need habitat which will allow them to go through parts of their life cycles in standing water. Many plants are also associated with pools of water or the moist depressions which are left after the water evaporates. Many of us recognize these plants as common weeds but weeds provide seeds for food, shelter for nesting, and habitat for a variety of fauna to move and live beneath.

Conservation is one stated purpose of the book. Some states have already identified the shallow pools of water present in the spring, and other provinces and states could easily identify similar regions using the criteria outlined here. People who wish to live in country settings often have to alter the natural setting which they have selected in order to build upon it. Developers build according to formulae which sell houses, not rustic settings where the best interests of nature are preserved. Builders choose level versus low-lying ground which leads to bulldozing depressions into lawns and woodlots into open areas. Environmental laws now define the

\section{Young NATURALISTS}

\section{Amazing Animal Journeys}

By Liam O'Donnell. 2008. Tourmaline Editions Inc./DK Publishing Canada. 48 pages. 4.99.CAD Paper.

\section{Snow Dogs! Racers of the North}

By Ian Whitelaw. 2008. Tourmaline Editions Inc./DK Publishing Canada, 662 King Street West, Suite 304, Toronto, Ontario, M5V 1M7. 48 pages. 4.99 CAD Paper.

Amazing Animal Journeys and Snow Dogs! Racers of the North, both by Canadian writers, are books about animals and travel. Amazing Animal Journeys, rated at DK Publishing's Level 3-Reading Alone, is the story of four long-distance wildlife migrations. Snow Dogs! Racers of the North, rated at Level 4-Proficient Readers, is about dogs and people travelling together in the north.

Of the two books, Snow Dogs! Racers of the North is the most coherent, mainly because it focuses on a single story line: dog sledding. The book is divided into 10 chapters covering topics that include the history of dog sledding, human-dog teamwork, descriptions of highprofile sled-dog races, and profiles of sled-dog racers. The information provided is comprehensive and interesting. The sentence structure is dynamic, flowing, and wetlands but the woodland depressions which form vernal pools have neither been identified nor are builders inclined to further limit the buildable space by looking for areas to preserve.

All researchers and professionals in the field who work in areas which are populated by vernal pools can benefit from this rich source. The available literature of flora, fauna, conservation and identification of vernal pools is shown for naturalists and conservationists alike. It has also built upon an earlier work by Elizabeth Colburn, Vernal Pools: Natural History and Conservation (Colburn 2004) and borrows heavily from her further research.

This book is a valuable resource in the identification and ecology of seasonal pools which support many amphibians, insects and invertebrates. Reptiles, birds and mammals are also occasional visitors and sometimes breeders. Human building pressures, pesticides, and conservation opportunities are all parts of the study forming the most comprehensive work I have seen on this topic to date. I was only able to read this book slowly because it contains so much research but found myself going back to sections for reference around related topics. It is well researched, carefully prepared and a valuable resource for conservationists.

\section{Literature Cited.}

Colburn, E.A. 2004. Vernal Pools: Natural History and Conservation. The MacDonald and Woodward Publishing Co., Blackburg, Virginia USA.

JIM O’NEILL

28718 Five Mile Road, Livonia, Michigan 48154 USA

appropriate to the reading level. And the illustrations, mainly photographs, as well as maps of dog-sled race routes, are plentiful and colourful.

All things considered, Snow Dogs! Racers of the North is an interesting, well-written book. My only complaint is with the title, which suggests a book about sled dogs. Yet the content of the book concentrates on sled-dog racing, races, and mushers. While dogs are depicted in most of the photographs, and mentioned on every page, the spotlight is not shone on them very often, and then only briefly.

Two of the book's 48 pages deal with breeds of sled dogs. One paragraph is dedicated to the roles played by dogs positioned at different points along the gangline. One photograph and three sentences portray Balto, the famous lead dog who guided the sled in the last leg of the heroic journey that inspired Alaska's renowned Iditarod Sled Dog Race. Oh yes, the name of another lead dog involved in that journey, Togo, was also mentioned.

The book's title led me to hope for at least one chapter on the various breeds of sled dog developed in differ- 
ent parts of the world. Another chapter portraying famous sled dogs, past and present, would have been fascinating, and would have helped round out the book and make it truer to its title. And I would have liked to see more information about the qualities sought for dogs playing different roles on a sled-dog team. The dogs, who work so hard, and who give so much to the sport - without whom the sport would not, in fact, be possible-deserve as much.

The focus of Amazing Animal Journeys is definitely on animals. And the stories it tells - about Barrenground Caribou, Monarch Butterfly, Gray Whale and Snow Goose migrations - are indeed amazing. While the book offers lots of terrific information and colourful illustrations, mainly photographs, it tries, in my opinion, to do too much.
Covering four complex wildlife migrations in 48 pages is itself an amazing feat. To do so successfully would have required either telling fewer migration stories more fully, or telling the same number of stories more simply. The author, unfortunately, tried to take the middle road, and the result is stories that jump around a little too much for smooth reading, and that don't provide enough links between details to make the information flow nicely. That said, the sentence structure is appropriate to the reading level, and the stories are certainly interesting.

Both books, however, left me wanting to know more. And that, perhaps, is not a bad thing.

RENATE SANDER-REGIER

3, 11th Line, Bristol, Quebec J0X 1G0 Canada

\section{New TitLes}

Prepared by RoY JoHN

$\dagger$ Available for review * Assigned

Currency Codes - CAD Canadian Dollars, USD U.S. Dollars, EUR Euros, AUD Australian Dollars, GBP Great Britain Pound.

\section{ZoOLOGY}

The Question of Animal Culture. Edited by Kevin N. Laland and Bennett G. Galef. 2009. Harvard University Press, 79 Garden Street, Cambridge, Massachusetts 02138 USA. 298 pages. 49.95 USD Cloth

$\dagger$ Animal Life. 2008. Tourmaline Editions Inc., DK Publishing Canada, 662 King Street West, Suite 304, Toronto, Ontario M5V 1M7 Canada. 512 pages. 55.00 CAD.

Oxford Dictionary of Biology [Sixth Edition]. By Elizabeth Martin and Robert S. Hine. 2008. Oxford University Press, 198 Madison Avenue, New York, New York 10016 USA. 704 pages. 19.95 USD Paper.

* Extreme Birds. By D. Couzens. 2008. Firefly Books Ltd. 66 Leek Crescent, Richmond Hill Ontario L4B 1H1 Canada. 281 pages. 45 CAD Cloth.

Feathered Dinosaurs: The Origin of Birds. By John Long. 2008. Oxford University Press, 198 Madison Avenue, New York, New York 10016 USA. 208 pages. 43.95 USD Cloth.

Witness to Extinction: How We Failed to Save the Yangtze Dolphin. By Samuel Turvey. 2008. Oxford University Press, 198 Madison Avenue, New York, New York 10016 USA. 256 pages. 32.95 USD Cloth.

Egg \& Nest. By Rosamond Purcell, Linnea S. Hall, and René Corado, 2008. Harvard University Press, 79 Garden Street, Cambridge, Massachusetts 02138 USA. 232 pages. 39.95 USD Cloth.

Fish of the Rockies. By Bill Gould, David Propst, Michael G. Sullivan. 2009. Lone Pine Publishing 206, 10426-81 Avenue, Edmonton, Alberta T6E 1X5 Canada. 208 pages. 18.95 CAD Paper.

* Frog. By Thomas Lorent. 2008. Nature / Tourmaline Editions Inc., DK Publishing Canada, 662 King Street West,
Suite 304, Toronto, Ontario, M5V 1M7 Canada. 280 pages 33.00 CAD Cloth.

Mountain Gorillas: Biology, Conservation, and Coexistence. By Gene Eckhart and Annette Lanjouw. 2008. The Johns Hopkins University Press, 2715 North Charles Street, Baltimore, Maryland 21218-4363 USA. 224 pages. 24.95 USD Cloth.

Organization of Insect Societies: From Genome to Sociocomplexity. Edited by Jürgen Gadau and Jennifer Fewell. 2009. Harvard University Press, 79 Garden Street, Cambridge, Massachusetts 02138 USA. 518 pages. 79.95 USD Cloth.

Men: Evolutionary and Life History. By Richard G. Bribiescas. 2008. Harvard University Press, 79 Garden Street, Cambridge, Massachusetts 02138 USA. 320 pages. 17.95 USD Paper.

Prairie Dogs: Communication and Community in an Animal Society. By C. N. Slobodchikoff, Bianca S. Perla, and Jennifer L. Verdolin. 2009. Harvard University Press, 79 Garden Street, Cambridge, Massachusetts 02138 USA. 280 pages. 39.95 USD Cloth.

The Beachcomber's Guide to Seashore Life in the Pacific Northwest. By J. Duane Sept. 2008. Harbour Publishing, PO Box 219, Madeira Park, British Columbia V0N 2H0 Canada. 240 pages. 26.95 USD Paper.

Squirrels of North America. By Tamara Eder. 2009. Lone Pine Publishing 206, 10426-81 Avenue, Edmonton, Alberta T6E 1X5 Canada. 160 pages. 16.95 CAD Paper.

* Return to Warden's Grove: Science, Desire and the Life of Sparrows. By Christopher Norment. 2008. Iowa University Press, 2121 State Avenue, Ames, Iowa 50014-8300 USA. 234 pages. 26.00 USD Cloth. 